\title{
COMPARATIVE CATAMNESTIC STUDIES OF TWO GROUPS OF PARAPLEGICS
}

\author{
By Priv.-Doz. Dr. H. WAHLE \\ Südwestdeutsches Rehabilitationskrankenhaus Karlsbad bei Karlsruhe \\ (W. Germany) \\ and \\ Professor Dr. K.-A. JochHeim \\ Rehabilitationszentrum der Universität zu Köln \\ (W. Germany)
}

IN the Federal Republic of Germany specific treatment of paraplegics was begun relatively late (Jochheim, I958; Meinecke, 1958; Paeslack, 1962; Wahle \& Jochheim, 1962). This is at least true for all those paraplegics not covered by the compulsory accident insurance and thus could not be admitted to the special wards maintained by Employers' Liability Insurances. The effects of inadequate paraplegic treatment were demonstrated in a catamnestic study of roo paraplegics who had sustained their lesions in the years between 1950 and 1958 (Wahle, 1965).

In this paper we want to compare the results obtained with a group of paraplegics from the 'fifties (Group 50) with those of a group of paraplegics from the 'sixties (Group 60). It was between these two decades that new treatment and rehabilitation facilities for paraplegics were established in the Federal Republic of Germany. But despite this development it should not be forgotten that the number of adequately equipped centres in Germany providing treatment for paraplegics is still insufficient (Meinecke, 1970).

In order to obtain comparable results we had to look for results that came from almost homogenous groups. Therefore, we decided to include only paraplegics with complete lesions. The comparison is not impaired by the fact that Group 50 included I5 paraplegics with subtotal lesions: this being the more negligible because their residual motility and sensibility was insignificant and not relevant for the function.

Not including the extent of lesions, the following features showed only slight differences in the two groups:

Proportions of lesions at lumbar and thoracic levels; there were no tetraplegics.

Age group distribution; there were no paraplegics under 14 and over 50 years of age.

Distribution as to sexes.

Distribution as related to the causes of lesions.

Distribution as regards financially responsible agencies; persons insured under the Employers' Liability scheme were not included.

All paraplegics had lesions of older than 2 years, at the date when the catamnestic study commenced.

Both groups had also benefited from antibiotic therapy.

From the great variety of criteria by which the success of rehabilitation can be measured, the following two criteria were selected: 
The number of paraplegics who had completed in-patient treatment by the end of 2 years and the number of those who had already been re-settled in employment at the same date. By applying this criteria the number of paraplegics eligible for the comparative study decreased. Thus, out of 100 paraplegics who had sustained their lesions in the 'fifties, $4 \mathrm{I}$ paraplegics who had received treatment in different Rhineland Hospitals remained for group 50. In the majority of cases these hospitals were not able to give adequate treatment to paraplegics because they had neither the required staff nor the equipment.

Out of I63 persons with spinal cord lesions of all degrees of severity and who had been treated at the Rehabilitation Centre of the University Hospitals in Cologne during the period of 1966 and 1970, 3I paraplegics remained for Group 60. Thus, the catamnesis of a total of 72 (4I group 50) paraplegics were evaluated.

To make comparison easier the figures are given in percentages although the patient populations are small.

\section{TABLE I}

Medical rehabilitation-results after two years

\begin{tabular}{|c|c|c|}
\hline & $\begin{array}{l}\text { 4I paraplegics } \\
\mathrm{T}_{0} \text { I } 950-\mathrm{I} 958\end{array}$ & $\begin{array}{l}3 \mathrm{I} \text { paraplegics } \\
\mathrm{T}_{0} \mathrm{I} 963-1969\end{array}$ \\
\hline $\begin{array}{l}\text { Paraplegics who are still receiving } \\
\text { in-patient treatment after two years }\end{array}$ & $6 \mathrm{I} \cdot 0 \%$ (25 Ppl.) & 19.4\% (6 Ppl.) \\
\hline $\begin{array}{l}\text { Paraplegics who have completed } \\
\text { hospital treatment }\end{array}$ & $39.0 \%$ (I6 Ppl.) & $80.6 \%$ (25 Ppl.) \\
\hline Total & I00.0\% (4I Ppl.) & $100.0 \%$ (3I Ppl.) \\
\hline
\end{tabular}

As to the first criterion, i.e. completion of in-patient treatment, the following comparative results were obtained:

The proportion of paraplegics who had completed in-patient treatment by the end of a 2-year period rose from 39 per cent. to 80 per cent. This difference is significant from the statistical point of view. It can therefore be said that in West Germany there is an overall improvement regarding the possibilities of rehabilitating paraplegics. But, in the 'sixties, six out of $3 \mathrm{I}$ paraplegics had to remain in the Cologne Rehabilitation Centre for more than 2 years. They had, however, received treatment in other hospitals before being admitted 12 or even more months after sustaining the lesion, because of an insufficient capacity of existing rehabilitation facilities for paraplegics. During this period of initial treatment these patients had frequently acquired severe complications; often not fully repairable.

As for the second criterion, i.e. vocational reintegration in the widest sense, the following comparative results were obtained:

The low percentage of 12.5 per cent. figuring those paraplegics of Group 5o who were vocationally reintegrated, undoubtedly shows that those paraplegics discharged 
from the hospital were frequently in an insufficient training condition. By comparison it will be seen that the rate of successful vocational rehabilitation is high in Group 60 ( 72 per cent.) and that this difference is indeed significant from the statistical point of view. However, it should not be forgotten that a considerable number of paraplegics are still receiving basic vocational training or are being retrained.

\section{TABLE II}

Vocational rehabilitation-results after two years

\begin{tabular}{|c|c|c|c|c|}
\hline \multirow{2}{*}{$\begin{array}{l}\text { Paraplegics with gainful employ- } \\
\text { ment }\end{array}$} & \multicolumn{2}{|c|}{$\begin{array}{l}\text { I6 paraplegics } \\
\mathrm{T}_{0} \text { I950-I958 }\end{array}$} & \multicolumn{2}{|c|}{$\begin{array}{l}25 \text { paraplegics } \\
\mathrm{T}_{0} \mathrm{I} 963-1969\end{array}$} \\
\hline & $\left.\begin{array}{c}0.0 \% \\
(0 \mathrm{Ppl} .)\end{array}\right)$ & & $\left.\begin{array}{l}20 \cdot 0 \% \\
(5 \mathrm{Ppl} .)\end{array}\right)$ & \\
\hline $\begin{array}{l}\text { Paraplegics who are doing domestic } \\
\text { work for at least five hours }\end{array}$ & $\left.\begin{array}{l}6 \cdot 2 \% \\
(\mathrm{I} \text { Ppl.) }\end{array}\right\}$ & $\begin{array}{l}\mathrm{I} 2 \cdot 5 \% \\
(2 \mathrm{Ppl} .)\end{array}$ & $\begin{array}{l}\text { I6.0\% } \\
(4 \mathrm{Ppl} .)\end{array}$ & $\begin{array}{l}72 \cdot 0 \% \\
(18 \mathrm{Ppl} .)\end{array}$ \\
\hline $\begin{array}{l}\text { Paraplegics who are receiving basic } \\
\text { vocational training or who are being } \\
\text { retrained }\end{array}$ & $\left.\begin{array}{c}6 \cdot 2 \% \\
(\text { I } \\
\text { Ppl.) }\end{array}\right)$ & & $\begin{array}{c}36 \cdot 0 \% \\
(9 \mathrm{Ppl} .)\end{array}$ & \\
\hline $\begin{array}{l}\text { Paraplegics who were vocationally } \\
\text { reintegrated }\end{array}$ & & $\begin{array}{l}\text { 12.5\% } \\
(2 \mathrm{Ppl} .)\end{array}$ & & $\begin{array}{l}72 \cdot 0 \% \\
\text { (18 Ppl.) }\end{array}$ \\
\hline $\begin{array}{l}\text { Paraplegics who were not vocation- } \\
\text { ally reintegrated }\end{array}$ & & $\begin{array}{l}87.5 \% \\
\text { (I } 4 \text { Ppl.) }\end{array}$ & & $\begin{array}{l}28.0 \% \\
(7 \mathrm{Ppl} .)\end{array}$ \\
\hline $\begin{array}{l}\text { Total number of paraplegics who } \\
\text { have completed in-patient treat- } \\
\text { ment }\end{array}$ & & $\begin{array}{l}\text { I00.0\% } \\
(\text { I6 Ppl.) }\end{array}$ & & $\begin{array}{l}100 \cdot 0 \% \\
(25 \mathrm{Ppl} .)\end{array}$ \\
\hline
\end{tabular}

It is planned to continue with these catamnestic studies, for only their results will illustrate whether or not medical and vocational rehabilitation efforts have lasting effects.

As causes of failure in the vocational resettlement of Group 60 it was stated at the date of follow-up examination-2 years after sustaining the lesion that:

in four cases, more or less, marked personality disorders were present, in two cases there were recurrent deep ischial decubitus ulcers, in one case financial security was so good, because of compensation through liability insurance, that there was no motivation to take up work at that time.

The results obtained with such small groups can not, of course, be regarded as representative. Therefore, the aforementioned results must be considered with caution, but nevertheless, even if one maintains a very critical attitude, a clear progress in the treatment of paraplegics in the Federal Republic of Germany must 
be admitted. And the authors certainly know that this progress would not have been a fact today without the pioneer work done by physicians in Great Britain and the United States after World War II.

\section{SUMMARY}

Two almost homogeneous groups of 72 paraplegics (57 total, I5 subtotal lesions) were compared 2 years after sustaining the lesion.

To enable a comparison the following two criteria were selected:

I. Percentage of paraplegics who had completed in-patient treatment at that date

2. Percentage of paraplegics who had already resumed work.

Only some of the paraplegics of Group 50 (sustained their lesions in the period between 1950 and 1958 ) had received treatment in special wards or units.

Paraplegics of Group 60 (sustained their lesions during the years of 1963 and I969) had received treatment in the Rehabilitation Centre of the University of Cologne. The cited results clearly prove that qualified specific treatment is of great effectiveness.

\section{REFERENCES}

Jochнeim, K.-A. (1958). Grundlagen der Rehabilitation in Deutschland. Arbeit und Gesundheit N. F. 64, Stuttgart: Thieme.

MEINECKE, F. W. (1958). Mschr. Unfallheilk. 61, I47-I52.

MeINECKE, F. W. (I 970). Dtsch. Ärztebl. 67, 4I 3-4I8 u. 506-5I I.

Paeslack, V. (1962). Med. Welt, 28, I507-1515.

WAHLE, H. (1965). Das Schicksal des Querschnittsgelähmten aus medizinischer und sozialer Sicht. Acta Neurochirurgica, Supp. XIV. Wien: Springer.

WahLe, H. \& Jochheim, K.-A. (I962). Ärztl. Mitt. Köln, 47, I98I-I984. 